\title{
Rye (Secale cereale L.) and Hairy Vetch (Vicia villosa Roth) Intercrop Management in Fresh-market Vegetables
}

\author{
Vasey N. Mwaja ${ }^{1}$ and John B. Masiunas ${ }^{2}$ \\ Department of Natural Resources and Environmental Sciences, University of Illinois, 1201 West Gregory \\ Drive, Urbana, IL 61801 \\ Catherine E. Eastman ${ }^{3}$ \\ Center for Economic Entomology, Illinois Natural History Survey, 607 East Peabody Drive, Champaign, \\ IL 61820 \\ Additional index words. biological control, integrated pest management, fertility, cabbage, Brassica oleracea var. Capitata, \\ snap bean, Phaseolus vulgaris, tomato, Lycopersicon esculentum

\begin{abstract}
The effect of cover-crop management on growth and yield of 'Bravo' cabbage (Brassica oleracea var. Capitata L.), 'Market Pride' tomato (Lycopersicon esculentum Mill.), and 'Mustang' snap bean (Phaseolus vulgaris L.) was determined. Each fall, 'Wheeler' winter rye (Secale cereale L.) and 'Oregon Crown' hairy vetch (Vicia villosa Roth) were interseeded. The following spring, the cover crops were killed by either applying glyphosate and mowing (CC-G) or mowing and disking (CC-D). Trifluralin was preplant incorporated into bare ground as a conventional tillage (CT) treatment. In 1992 and 1993, a chicken (Gallus gallus $\mathrm{L}$.) based fertilizer was applied to half the subplots. The greatest snap bean and cabbage yields were in CT. The system with the greatest tomato yields varied. In 1991, the greatest tomato yields were in the CT treatment, while in 1992 yields were greatest in the CT and CC-D treatments, and in 1993 the greatest yields were in CT and CC-G. Cabbage yields were greater in the fertilized than the unfertilized treatments. In 1992, infestations of diamondback moth, imported cabbageworm, and cabbage looper were greater in CT than in the CC-G treatment. Three years of the CC-G treatment increased soil organic matter from $3.07 \%$ to $3.48 \%$ and increased soil pH from 6.30 to 6.51, while neither changed in the CT. Chemical names used: $N$-(phosphonomethyl) glycine (glyphosate); 2,6-dinitro$N, N$-dipro'pyl-4-(trifluoromethyl) benzenamine (trifluralin).
\end{abstract}

Cover crop mulch systems often use fall-planted small grains or legumes to produce residues for spring-planted vegetables. These systems can modify the microenvironment of the crop, affecting pest populations and vegetable crop yields. Generally, cover-crop mulch systems decrease water evaporation and increase infiltration, resulting in greater soil moisture (Knavel and Herron, 1986; Schonbeck et al., 1993). The higher soil moisture levels in covercrop mulch systems lower soil temperatures, which can delay growth of early season vegetables (Knavel and Herron, 1986). However, if a cereal rye cover crop grows excessively during the early spring, soil moisture may be significantly depleted (Drost and Price, 1991).

Cover crop mulch systems also can affect the chemical properties of soils. For example, Eckert (1991) reported that covercropping with rye increased soil pH in continuous corn (Zea mays), but not in soybean (Glycine max). The increase in $\mathrm{pH}$ was attributed to an assimilation of $\mathrm{N}$ by the rye. Cover crop residues may make $\mathrm{N}$ unavailable to vegetable crops due to assimilation or denitrification (Skarphol et al., 1987). Cover crops can also in-

Received for publication 4 Aug. 1995. Accepted for publication 19 Jan. 1996. From a thesis submitted by V.N.M. in partial fulfillment of the requirements for a $\mathrm{PhD}$ degree. This project was partially supported by Hatch and North Central Region Sustainable Agriculture Research and Education Program funding. Mention of a trademark, propriety product, or vendor does not constitute a guarantee or warranty of the product by the Univ. of Illinois or the Illinois Natural History Survey, and does not imply its approval to the exclusion of other products or vendors that also may be suitable. The cost of publishing this paper was defrayed in part by the payment of page charges. Under postal regulations, this paper therefore must be hereby marked advertisement solely to indicate this fact.

${ }^{1}$ Former graduate student. Current address: Bayer E.A., P.O. Box 30321, Nairobi, Kenya.

${ }^{2}$ Associate professor; to whom reprint requests should be addressed.

${ }^{3}$ Associate professional scientist. crease nitrogen available for vegetables either by the decomposition of legume residues or by preventing $\mathrm{N}$ losses during the winter (Doss et al., 1981; Hairston et al., 1987; Knavel and Herron, 1986). Rye also increases the concentration of exchangeable potassium near the soil surface (Eckert, 1991).

Cover crop mulch systems can reduce weed emergence and growth. They alter the light stimulus needed for emergence of certain weeds (More et al., 1994), and can release allelochemicals that inhibit weed growth (Barnes and Putnam, 1983; Mwaja et al., 1995). The surface coverage of rye or hairy vetch residues is positively correlated with weed suppression (Teasdale et al., 1991). Although rye and hairy vetch residues may suppress weed growth, supplemental weeding of the crop is required for seasonlong weed control (Curran et al., 1994; Masiunas et al., 1995; Mwaja and Masiunas, 1995; Teasdale, 1993). Weed suppression with hairy vetch residues is generally poor.

Reduced tillage, common in cover-crop mulch systems, can conserve beneficial insects (Bugg, 1992). For example, many predatory wasps nest in the ground and tillage interferes with their reproduction (Bugg et al., 1990). Cover crop mulches also may reduce pest dispersal, reproduction, and colonization of host plants. Plant compounds released by cover-crop residues may influence host plant selection for oviposition and larval feeding (Rice, 1984). Cover crop mulches can confuse pests visually or olfactorally, reducing colonization of vegetable crops (Andow, 1991).

There are several reports of similar fresh-market tomato yields from cover-crop mulch systems and from conventional tillage (Drost and Price, 1991; Knavel and Herron, 1986; Masiunas et al., 1995) and Skarphol et al. (1987) found that snap bean yields from plots with hairy vetch were similar to those from conventional tillage. However, vegetable crop growth and yield can be affected by rye and hairy vetch mulches. Knavel and Herron (1986) 
reported that poor coverage of snap bean seed planted into hairy vetch residues reduced yields. Rye or hairy vetch can reduce cabbage yields (Knavel and Herron, 1986; Schonbeck et al., 1993). Rye residues have a high carbon-to-nitrogen ratio and their decomposition could be immobilizing soil nitrogen, reducing cabbage yields (Schonbeck et al., 1993).

Intercropping hairy vetch with rye may not deplete soil $\mathrm{N}$ during decomposition and may produce less allelopathic effects on vegetable crops while protecting the soil and reducing pest populations. Incorporating residues of hairy vetch may increase their ability to supply $\mathrm{N}$ to subsequent vegetable crops. Neither the impact of a hairy vetch-rye intercrop nor the effect of residue placement on vegetable crop yields has been determined. The objectives of our study were to determine the impacts of rye and hairy vetch residues and either surface placement or incorporation by disking on snap bean, cabbage, and tomato growth and yield. We also observed effects of the cover crops on some soil properties and insect pests.

\section{Materials and Methods}

This study was conducted from 1990-93 at the Univ. of Illinois Cruse Vegetable Crop Research Farm in Champaign, Ill. The soil type was a Flanagan silt loam (fine montimorrillontic, mesic, Aquic Arguidoll; pH 6.3 to 6.6 and organic matter $3.1 \%$ to $3.3 \%$ ). Between 11 Sept. and 2 Oct. of each year, the experimental site was moldboard plowed and disked. The cover-crop treatments of 'Wheeler' cereal rye and 'Oregon Crown' hairy vetch were then drilled in 20-cm rows at 112 and $34 \mathrm{~kg} \cdot \mathrm{ha}^{-1}$, respectively. In 1991, most of the cover crop winter-killed and was replanted on 4 Mar. 1992. Unseeded bare ground plots were established for the conventional tillage (CT) treatment.

In May, one week before planting vegetables, the rye and hairy vetch were killed either by applying glyphosate at $1.1 \mathrm{~kg} \cdot \mathrm{ha}^{-1}$ a.e. and mowing (CC-G) or by mowing and two passes with a disk (CCD). Trifluralin at $0.84 \mathrm{~kg} \cdot \mathrm{ha}^{-1}$ a.i. was preplant incorporated in the CT plots. The plots received the same cover-crop management system each year. All three vegetable crops were grown in each management system every year, but they were rotated in a cabbage-tomato-snapbean-cabbage sequence.

Tomato and cabbage transplants were grown in 72-cell flats filled with a 1:1 mixture of peatmoss and horticultural grade vermiculite (w/w) under greenhouse conditions as described in Perez and Masiunas (1990). Between 22 May and 5 June, sixweek-old seedlings were hand-transplanted into each plot. Between 23 May and 8 June, snap beans were seeded at 172000 seed /ha to a 4- to 6-cm depth using a no-till planter. The subplots were $77 \mathrm{~m}^{2}$ and contained either three rows of tomato or cabbage, or four rows of snap bean. Spacing between tomato and cabbage rows was $0.90 \mathrm{~m}$ and within the row was $0.46 \mathrm{~m}$. Snap beans were spaced at $0.75 \mathrm{~m}$ between rows and about $3 \mathrm{~cm}$ within the row.

Standard cultural practices for fresh market vegetables were used. The tomatoes were staked using a Florida weave system (Swiader et al., 1993). Weeds were removed every 2 weeks by hand (all treatments) and cultivation (CT only). Rainfall was supplemented with $0.6 \mathrm{~cm}$ of overhead sprinkler irrigation every 2 weeks in 1991, but only twice during each of the other years. Initial nitrogen levels were not assessed, but other nutrients were adequate for vegetable growth. In 1992 and 1993, a chicken (Gallus gallus L.) manure-based fertilizer (Greenview certified organic fertilizer, Greenview, Lebanon, Pa.) was applied to half of the subplots at $25 \mathrm{~N}-33 \mathrm{P}-46 \mathrm{~K} \mathrm{~kg} \cdot \mathrm{ha}^{-1}$ for cabbage, and $38 \mathrm{~N}-50 \mathrm{P}-$ $70 \mathrm{~K} \mathrm{~kg} \cdot \mathrm{ha}^{-1}$ for tomato. The snap beans were not fertilized.
The height of six randomly selected crop plants from the center rows was measured every 2 weeks starting 2 weeks after planting (WAP). A 3-m section of plants was harvested from the center row of cabbage and tomato and the center two rows of snap bean for crop yield determinations. Snap beans and tomatoes were handharvested every 3 days beginning 8 and 12 WAP, respectively. Tomato fruit were harvested at the breaker to firm ripe stage for 3 weeks, and snap beans were harvested for 2 weeks. Early yields were defined as the first two harvests of tomatoes or snap beans. Cabbage heads were harvested and weighed on 26 Aug. 1991, 3 Sept. 1992, and 25 Aug. 1993.

The soil was sampled in September 1990 before rye and hairy vetch were seeded, then again in September 1993 after the last vegetable harvest. Five samples were taken with a soil auger to a $15-\mathrm{cm}$ depth from near the center of each plot, and thoroughly mixed to make a composite sample. The soil samples were analyzed by a commercial laboratory (A and L Great Lakes Laboratories, Fort Wayne, Ind.) for organic matter, $\mathrm{pH}$, cation exchange capacity (CEC), and $\mathrm{P}, \mathrm{K}, \mathrm{Mg}$, and $\mathrm{Ca}$.

Cabbage head damage was assessed 12 WAP by randomly harvesting five cabbage plants from the center row and rating the extent of insect feeding on a scale of 1 (no damage) to 5 (severe damage) (Dickson and Eckenrode, 1980). The insects found on cabbage were counted during the 1992 and 1993 growing seasons. At 3 WAP, the insects were counted in situ on each leaf of five randomly selected plants per sub-subplot. At 7 WAP, a destructive sample of five plants per sub-subplot was taken to determine the insect species and their stages of development.

The experiment was a split-split plot design with four replications. The management system treatments were applied to main plots, vegetable crops were applied to subplots, and fertilizer treatments were applied to the sub-subplots (1992 and 1993 only). Treatment effect on the growth and yield were analyzed separately for each vegetable crop by analysis of variance (ANOVA) using the general linear model (GLM) procedure of the Statistical Analysis System (SAS Inst., Cary, N.C.) When necessary, data were $\log$ transformed to satisfy additivity and homogeneity of variance requirements of ANOVA. Treatment means were separated using protected Fisher's least significant difference test $(P=$ $0.05)$ or Waller-Duncan Bayesian $\mathrm{K}$ ratio $t$ test $(\mathrm{K}$ ratio $=100)$ (insect counts) (Bushnell et al., 1991). Crop height data were analyzed using regression analysis.

\section{Results and Discussion}

The crop height response to treatments was consistent over the 3 years, as indicated by nonsignificant management system $\times$ year and management system $\times$ fertility $\times$ year interactions. In general, growth in height could be described by linear or quadratic functions. Snap bean growth in the CC-G and CC-D treatments was similar (Fig. 1). In the CT treatment growth was slower initially but by 8 WAP the plants were taller than in the cover-crop treatments.

Cabbage and tomato response to management system was affected by fertilizer treatment. In general, plants grew taller in the fertilized sub-subplots. If unfertilized, cabbage grew best in the CC-G treatment (Fig. 2). If fertilized, growth was similar in the CC$\mathrm{G}$ and $\mathrm{CT}$ treatments and greater than in the CC-D treatment at 8 WAP. Tomato plant height in the unfertilized CC-D and CT treatments was similar (Fig. 3). In the fertilized sub-subplots at 6 and 8 WAP, the shortest tomatoes were in the CC-D treatment. The differences in response of cabbage and tomato to added fertility might be due to deeper rooting or more efficient uptake and utilization of nutrients by the tomatoes or the heavy use of nitrogen by the cabbage 


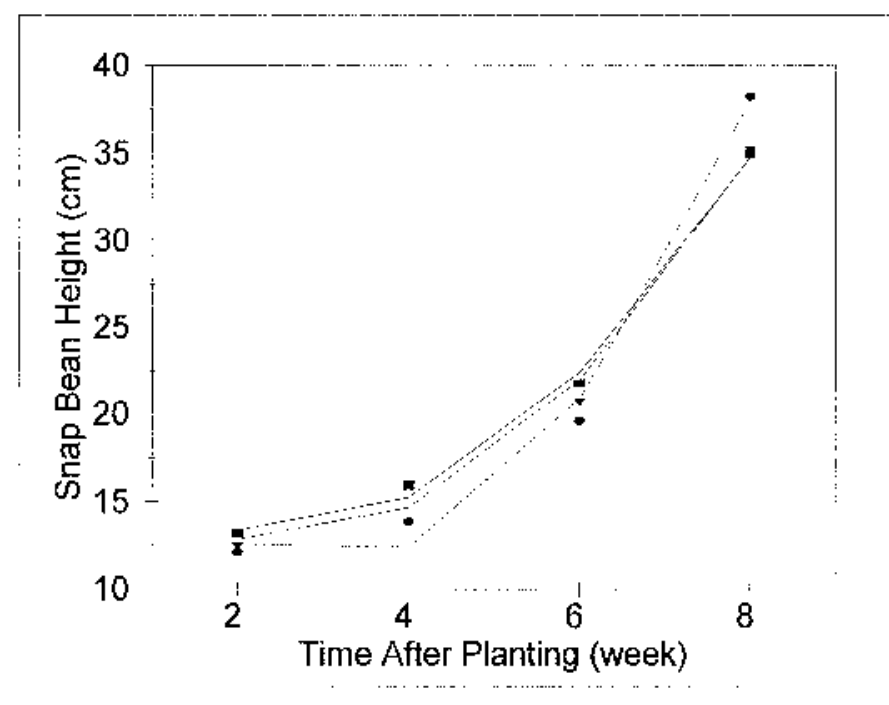

Fig. 1. The effect of cover-crop management on snap bean height. Results are averaged over year. The lines are the best-fix regression equations and the symbols are the means. The regression equations are $\mathrm{CC}-\mathrm{G}(-, \mathbf{\square}) \mathrm{Y}=16.7-2.98$ $\mathrm{X}+0.654 \mathrm{X}^{2}\left(\mathrm{Y}=\right.$ height in $\mathrm{cm}, \mathrm{X}=\mathrm{WAP}$, and $\left.r^{2}=0.97\right)$; CC-D $(\ldots \ldots . ., \boldsymbol{\Delta}) \mathrm{Y}$ $=16.6-3.23 \mathrm{X}+0.688 \mathrm{X}^{2}\left(r^{2}=0.80\right)$; and CT $(-----, 0) \mathrm{Y}=21.4-6.57 \mathrm{X}+1.08$ $\mathrm{X}^{2}\left(r^{2}=0.98\right)$.

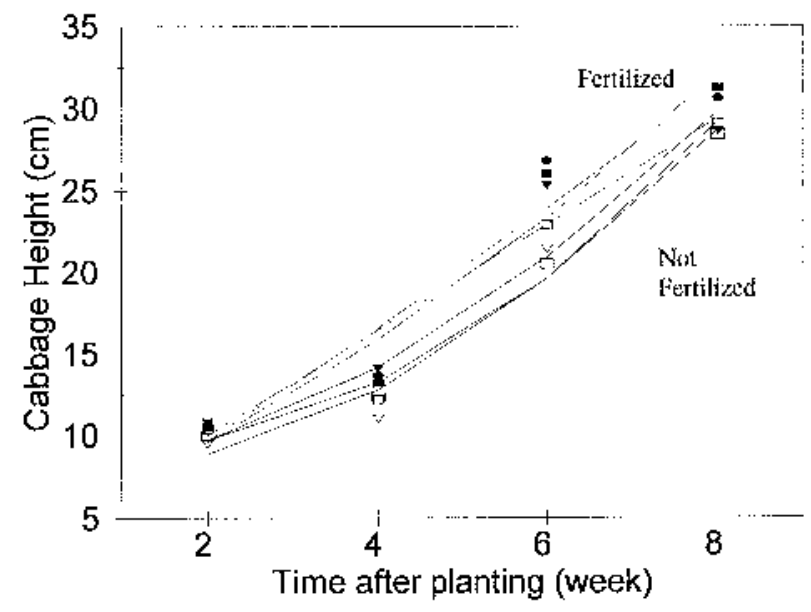

Fig. 2. The effect of cover-crop management and fertility on cabbage height. Results are averaged over year. The lines are the best-fix regression equations and the symbols are the means. The regression equations for cabbage with no fertilizer (一) are CC-G ( $(\square) \mathrm{Y}=7.45+0.59 \mathrm{X}+0.275 \mathrm{X}^{2}(\mathrm{Y}=$ height in $\mathrm{cm}$, $\mathrm{X}=\mathrm{WAP}$, and $\left.r^{2}=0.96\right)$; CC-D $(\Delta) \mathrm{Y}=8.86-0.27 \mathrm{X}+0.344 \mathrm{X}^{2}\left(r^{2}=0.98\right)$; and CT $(\bigcirc) \mathrm{Y}=7.84-0.178 \mathrm{X}+0.356 \mathrm{X}^{2}\left(r^{2}=0.97\right)$. For cabbage with fertilizer $(\ldots \ldots .$.$) , the regression equations are CC-G (\square) \mathrm{Y}=4.65-2.18 \mathrm{X}+0.156 \mathrm{X}^{2}\left(r^{2}\right.$ $=0.95) ; \mathrm{CC}-\mathrm{D}(\mathbf{\Delta}) \mathrm{Y}=3.55+3.23 \mathrm{X}\left(r^{2}=0.94\right)$; and CT $(\mathbf{O}) \mathrm{Y}=3.25+3.14$

Cool wet soil conditions found under hairy vetch and rye residues have been shown to reduce the height of corn in Michigan (Drost and Price, 1991; Johnson et al., 1993). We did not find a consistent height reduction by cover-crop residues. The difference in crops or in planting time may explain the inconsistency from previous reports. For example, corn might be more responsive to cool wet soils than were cabbage, tomato, and snap beans.

Tomato early yield was greater in 1993 than in other years (Table 1). The rainy weather delayed the first harvest and warmer temperatures during the 1993 growing season (Fig. 4) may have accelerated plant growth and reproductive development. Tomato

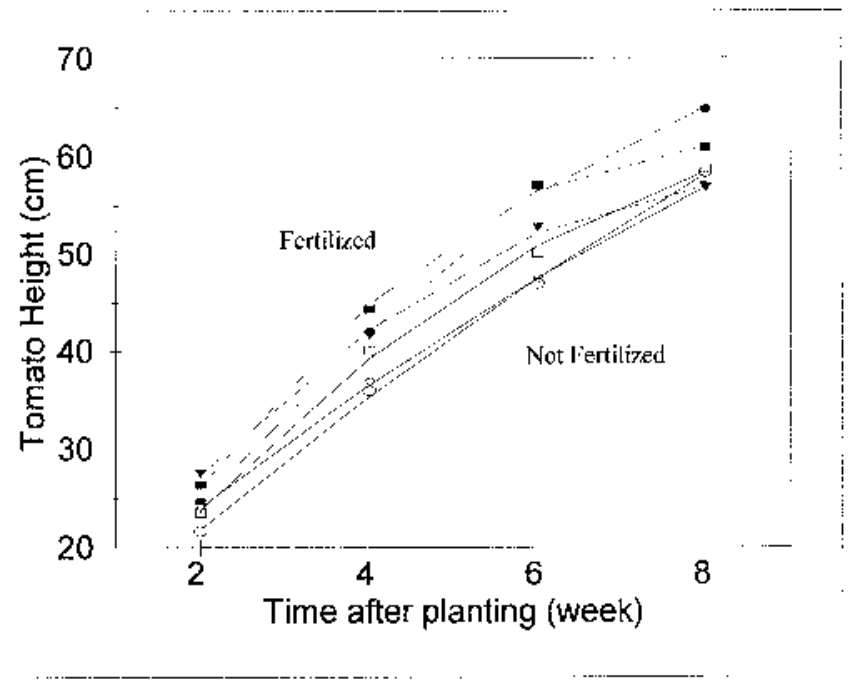

Fig. 3. The influence of cropping system and fertility on tomato height. The tomatoes were staked and results are averaged over year. The lines are the bestfix regression equations and the symbols are the means. The regression equations for tomatoes with no fertilizer $(-)$ are $\mathrm{CC}-\mathrm{G}(\square) \mathrm{Y}=4.26+10.76 \mathrm{X}-0.498 \mathrm{X}^{2}$ ( $\mathrm{Y}=$ height in $\mathrm{cm}, \mathrm{X}=\mathrm{WAP}$, and $\left.r^{2}=0.99\right)$; CC-D $(\Delta) \mathrm{Y}=9.91+7.47 \mathrm{X}+0.199$ $\mathrm{X}^{2}\left(r^{2}=0.98\right)$; and CT (O) $\mathrm{Y}=6.83+7.87 \mathrm{X}-0.181 \mathrm{X}^{2}\left(r^{2}=0.99\right)$. For tomatoes with fertilizer (....), the regression equations are $\mathrm{CC}-\mathrm{G}(\boldsymbol{\Delta}) \mathrm{Y}=0.37+14.7 \mathrm{X}-$ $0.884 \mathrm{X}^{2}\left(r^{2}=0.98\right)$; CC-D $(\mathbf{\Delta}) \mathrm{Y}=7.40+11.2 \mathrm{X}-0.629 \mathrm{X}^{2}\left(r^{2}=0.99\right)$; and CT (O) $\mathrm{Y}=1.47+12.7 \mathrm{X}+0.59 \mathrm{X}^{2}\left(r^{2}=0.99\right)$.

Table 1. The effect of cover-crop management and fertilization on the early yields of tomato and snap bean.

\begin{tabular}{|c|c|c|c|c|c|c|}
\hline \multirow{3}{*}{$\begin{array}{l}\text { Management } \\
\text { system }^{\mathrm{y}}\end{array}$} & \multicolumn{4}{|c|}{ Tomato early yield $^{\mathrm{z}}$} & \multirow{2}{*}{\multicolumn{2}{|c|}{ Snap bean early yield }} \\
\hline & \multicolumn{2}{|c|}{ No fertilizer } & \multicolumn{2}{|c|}{ Fertilizer } & & \\
\hline & 19911992 & 1993 & 1992 & 1993 & 19911992 & 1993 \\
\hline \multicolumn{7}{|c|}{$M g \cdot h a^{-1}$} \\
\hline CC-G & $3.7 \mathrm{a}^{\mathrm{w}} 1.7 \mathrm{~b}$ & 10.7 & $3.3 \mathrm{~b}$ & $25.3 \mathrm{a}$ & $0.3 \mathrm{~b} \quad 1.3$ & $1.3 \mathrm{~b}$ \\
\hline CC-D & $1.8 \mathrm{~b} \quad 5.5 \mathrm{a}$ & 10.6 & $6.5 \mathrm{a}$ & $10.7 \mathrm{~b}$ & $0.7 \mathrm{ab} 1.6$ & 1.2 \\
\hline $\mathrm{CT}$ & $2.5 \mathrm{~b} \quad 2.0 \mathrm{~b}$ & 13.5 & $5.2 \mathrm{a}$ & $23.4 \mathrm{a}$ & $1.2 \mathrm{a} \quad 1.8$ & $2.8 \mathrm{a}$ \\
\hline
\end{tabular}

${ }^{\mathrm{z}}$ Early yield is defined as the first two harvests.

${ }^{\mathrm{y}}$ Management systems were CC-G, rye and hairy vetch killed with glyphosate and mowed; CC-D, rye and hairy vetch mowed and disked; and $\mathrm{CT}$, conventional tillage with trifluralin.

XIn 1992 and 1993, chicken manure-based fertilizer was applied at 38, 50 , and $70 \mathrm{~kg} \cdot \mathrm{ha}^{-1} \mathrm{~N}, \mathrm{P}$, and $\mathrm{K}$, respectively for tomato. Snap beans were not fertilized.

${ }^{w}$ Mean separation within columns by Fisher's LSD, $P=0.05$.

early yield also was affected by fertilizer application. In the unfertilized sub-subplots, early yields in the cover-crop treatments were equal or greater than $\mathrm{CT}$ (Table 1). When the tomatoes were fertilized, early yields in the CT treatment were greater than those for the CC-G treatment in 1992 and the CC-D treatment in 1993.

Tomato yields were greater in 1991 than the other years (Table 2), possibly because it was warmer and drier in 1991 (Fig. 4) which could lead to earlier ripening. Since we only harvested ripe tomatoes, the faster they ripened the greater the yield. In 1991, the yields in the CT treatment were 1.5 times greater than yields in the cover-crop treatments. This high yield may have been due to a favorable microenvironment and adequate levels of fertility in the CT compared to cover-crop treatments.

In 1992 and 1993, when fertilizer treatments were applied, tomato yields in the unfertilized sub-subplots did not differ between cropping systems (Table 2). When fertilized sub-subplots were compared, total tomato yields were greatest in the CT and 
Table 2. Cover-crop management and fertilization influence on total yields of cabbage, tomato, and snap bean.

\begin{tabular}{|c|c|c|c|c|c|c|c|c|c|c|c|c|c|}
\hline \multirow{3}{*}{$\begin{array}{l}\text { Mangement } \\
\text { system }^{y}\end{array}$} & \multicolumn{5}{|c|}{ Tomato yield } & \multirow{2}{*}{\multicolumn{3}{|c|}{$\frac{\text { Snap bean yield }}{\text { No fertilizer }}$}} & \multicolumn{5}{|c|}{ Cabbage yield } \\
\hline & \multicolumn{3}{|c|}{ No fertilizer } & \multicolumn{2}{|c|}{ Fertilizer $^{\mathrm{z}}$} & & & & \multicolumn{3}{|c|}{ No Fertilizer $^{2}$} & \multicolumn{2}{|c|}{ Fertilizer $^{2}$} \\
\hline & 1991 & 1992 & 1993 & 1992 & 1993 & 1991 & 1992 & 1993 & 1991 & 1992 & 1993 & 1992 & 1993 \\
\hline \multicolumn{14}{|c|}{$M g \cdot h a^{-1}$} \\
\hline CC-G & $45.7 b^{x}$ & 21.0 & 25.5 & $25.4 \mathrm{~b}$ & $43.3 \mathrm{a}$ & $2.8 \mathrm{~b}$ & $4.6 \mathrm{~b}$ & $3.6 \mathrm{~b}$ & $53.0 \mathrm{ab}$ & $28.9 \mathrm{~b}$ & $17.2 \mathrm{~b}$ & $32.1 \mathrm{c}$ & $22.7 \mathrm{~b}$ \\
\hline CC-D & $47.1 \mathrm{~b}$ & 25.4 & 22.7 & $33.0 \mathrm{a}$ & $25.7 \mathrm{~b}$ & $3.9 \mathrm{~b}$ & $4.9 \mathrm{~b}$ & $3.3 \mathrm{~b}$ & $43.6 \mathrm{~b}$ & $36.9 \mathrm{~b}$ & $14.8 \mathrm{~b}$ & $51.5 \mathrm{~b}$ & $23.0 \mathrm{~b}$ \\
\hline CT & $70.4 \mathrm{a}$ & 23.2 & 27.9 & $33.5 \mathrm{a}$ & $37.0 \mathrm{a}$ & $5.6 \mathrm{a}$ & $7.1 \mathrm{a}$ & $6.9 \mathrm{a}$ & $60.3 a$ & $56.6 \mathrm{a}$ & $36.7 \mathrm{a}$ & $69.2 \mathrm{a}$ & $46.0 \mathrm{a}$ \\
\hline
\end{tabular}

${ }_{\mathrm{z}}$ In 1992 and 1993, chicken manure-based fertilizer was applied at 25, 33, and $46 \mathrm{~kg} \cdot \mathrm{ha}^{-1} \mathrm{~N}, \mathrm{P}$, and K, respectively, for cabbage and at 38, 50 , and 70 $\mathrm{kg} \cdot \mathrm{ha}^{-1} \mathrm{~N}, \mathrm{P}$, and K, respectively, for tomato. Snap beans were not fertilized.

yManagement systems were CC-G, rye and hairy vetch killed with glyphosate and mowed; CC-D, rye and hairy vetch mowed and disked; and CT, conventional tillage.

${ }^{x}$ Mean separation (in columns) by Fisher's LSD, $P=0.05$.
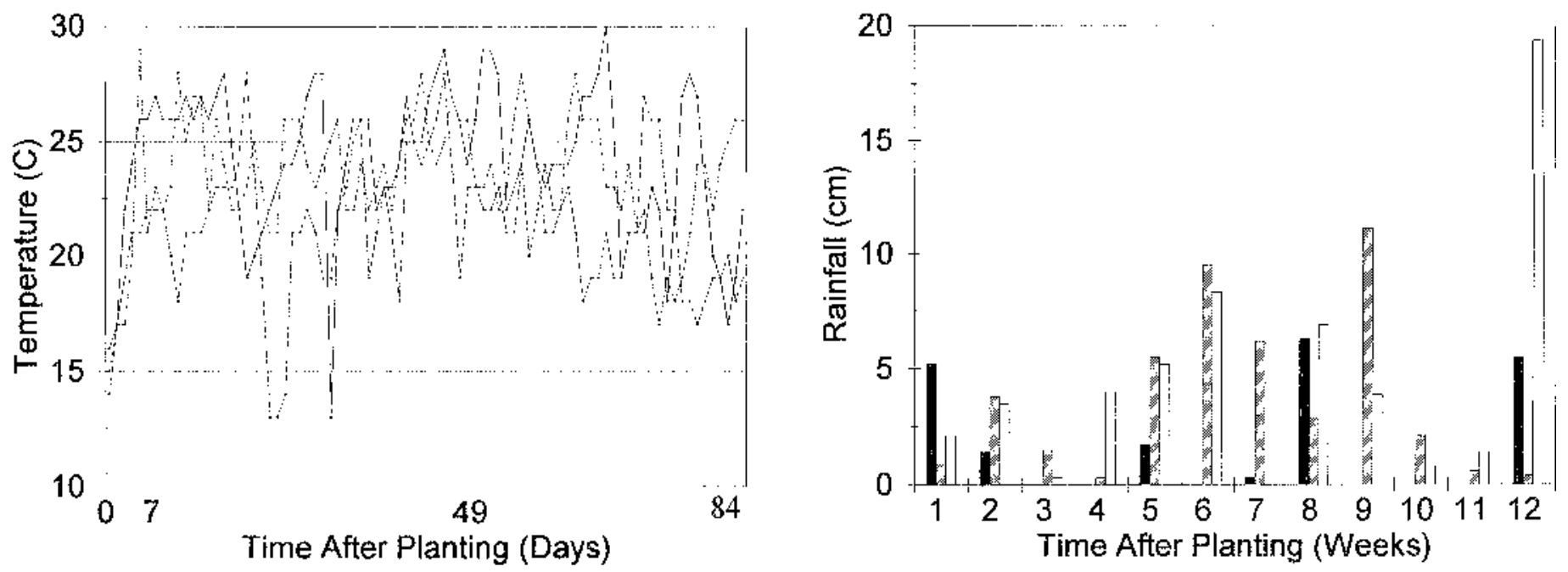

Fig. 4. Mean air temperatures (a) and weekly rainfall totals (b) for the 1991, 1992, and 1993 growing seasons at Champaign, Ill. The symbols for 1991 are the solid line and solid-filled bars, the 1992 symbols are the dashed line and dashed bars, and the symbols for 1993 are the dotted line and open bars. The Illinois Water Survey weather station was $<1$ kilometer from the experimental site.

CC-D (1992) or CC-G (1993) treatments. Other researchers have reported similar yields for tomatoes grown in no-till with rye or hairy vetch and in CT (Dickson and Eckenrode, 1980; Drost and Price, 1991; Knavel and Herron, 1986; Masiunas et al., 1995). Even though tomato yields were reduced in some treatments possibly by low soil $\mathrm{N}$, cooler soil temperatures, or allelopathy, all yields were comparable to the average commercial yield of 22.4 $\mathrm{Mg} \cdot \mathrm{ha}^{-1}$ (Lorenz and Maynard, 1988).

Snap bean early yields in 1991 and 1993 were greatest in the CT and lowest in the CC-G treatment (Table 1). In 1992, there were no differences in early yields. The delay in snap bean and tomato maturity with cover-crop mulch systems is a drawback because early fresh market vegetables often demand a market premium.

Total snap bean yields were greater by about 2 to $3 \mathrm{Mg} \cdot \mathrm{ha}^{-1}$ in the CT treatment than in either of the cover-crop treatments (Table 2). Knavel and Herron (1986) also found that snap bean yields were greater in CT compared to no-till with hairy vetch. They attributed the lower yields to a reduction in plant stand because the hairy vetch residues prevented the seed from reaching the soil. We did not observe any snap bean disease problems, stand reductions, or problems with seeding in the cover-crop treatments (data not shown). The lower snap bean yields and the chlorotic growth in these treatments may have been due to nitrogen immobilization during mulch decomposition or release of allelochemicals by the residues.

Except for 1991, cabbage yields were greater by 10 to 20
$\mathrm{Mg} \cdot \mathrm{ha}^{-1}$ in CT than the cover-crop treatments (Table 2). Fertilizing the crop did not overcome the reduction in yields caused by cover crops. Schonbeck et al. (1993) and Knavel and Herron (1986) also reported cabbage yields to be greater with CT than cover-crop treatments. Rye residues with a high C-to-N ratio may reduce cabbage yields by immobilizing $\mathrm{N}$ (Schonbeck et al., 1993). In our study, the decline in cabbage yields over the 3 years also suggests that $\mathrm{N}$ may have been limiting. Further research is needed to evaluate nitrogen effects on cabbage yields in covercrop systems.

Insect damage to cabbage heads was affected by management systems but not by fertilizer application. In all three years, insect damage was 1 to 2 rating points less in the CC-G than in the CT treatment (Table 3). The insect damage was caused by larvae of the diamondback moth (Plutella xylostella L.), cabbage looper (Trichoplusia ni Hubner), and imported cabbageworm (Pieris rapae L.) feeding on the heads. Diamondback moth, imported cabbageworm, and cabbage looper, occur together as a caterpillar complex and are the most important species of Lepidoptera attacking cabbage in the midwestern United States. In both 1992 and 1993, at 3 WAP there were no visible larvae of the imported cabbageworm and cabbage looper present in the samples (data not shown). Egg counts at $3 \mathrm{WAP}$, followed the same trends as larval data at 7 WAP. There were fewer caterpillars on cabbage at 7 WAP in 1993 than in 1992 (Table 3). In 1993, rainfall occurred through- 
Table 3. The influence of cover-crop management on insect damage to cabbage heads and the population of immatures (larval and pupal stages) of the cabbage caterpillar complex. ${ }^{\mathrm{z}}$

\begin{tabular}{|c|c|c|c|c|c|c|c|c|c|}
\hline \multirow{3}{*}{$\begin{array}{l}\text { Management } \\
\text { system }^{w}\end{array}$} & & & & \multicolumn{6}{|c|}{ Cabbage pests $^{\mathrm{y}}$ (no./plant) } \\
\hline & \multicolumn{3}{|c|}{$\begin{array}{l}\text { Damage } \\
\text { ratings }\end{array}$} & \multicolumn{2}{|c|}{$\begin{array}{l}\text { Diamondback } \\
\text { moth }\end{array}$} & \multicolumn{2}{|c|}{$\begin{array}{c}\text { Imported } \\
\text { cabbageworm }\end{array}$} & \multicolumn{2}{|c|}{$\begin{array}{c}\text { Cabbage } \\
\text { looper }\end{array}$} \\
\hline & 1991 & 1992 & 1993 & 1992 & 1993 & 1992 & 1993 & 1992 & 1993 \\
\hline$\overline{\mathrm{CC}-\mathrm{G}}$ & $1.0 \mathrm{~b}^{\mathrm{V}}$ & $1.7 \mathrm{~b}$ & $3.3 \mathrm{~b}$ & $3.2 \mathrm{~b}$ & $0.1 \mathrm{a}$ & $2.8 \mathrm{~b}$ & $1.1 \mathrm{a}$ & $0.4 \mathrm{~b}$ & $0.1 \mathrm{~b}$ \\
\hline CC-D & $4.0 \mathrm{a}$ & $3.2 \mathrm{a}$ & $3.8 \mathrm{~b}$ & $6.1 \mathrm{a}$ & $0.1 \mathrm{a}$ & $2.3 \mathrm{~b}$ & $1.2 \mathrm{a}$ & $1.9 \mathrm{a}$ & $0.1 \mathrm{~b}$ \\
\hline $\mathrm{CT}$ & $4.3 \mathrm{a}$ & $3.2 \mathrm{a}$ & $4.6 \mathrm{a}$ & $7.9 \mathrm{a}$ & $0.2 \mathrm{a}$ & $5.0 \mathrm{a}$ & $1.1 \mathrm{a}$ & $2.2 \mathrm{a}$ & $0.6 \mathrm{a}$ \\
\hline
\end{tabular}

ZInsect counts from the 7 WAP destructive sampling in 1992 and 1993. Damage ratings made 12 WAP.

yInsect counts were transformed using the square root before analysis. Nontransformed means are presented in the table.

Insect damage ratings on cabbage heads at harvest were done using a scale of $1=$ no damage to $5=$ severely damaged.

${ }^{w}$ Management systems were: CC-G, rye and hairy vetch killed with glyphosate and mowed; CC-D, rye and hairy vetch mowed and disked; and CT, conventional tillage with trifluralin.

${ }^{\mathrm{v}}$ Mean separation within columns by Fishers LSD, $P=0.05$ (damage ratings) or Waller-Duncan Bayesian K-ratio $t$ test, K-ratio $=100$ (insect counts)

Table 4. The soil tests for the field plots in 1990, before seeding hairy vetch and cereal rye, and in 1993 after a 3-year rotation of vegetable crops grown in three management systems.

\begin{tabular}{|c|c|c|c|c|c|c|c|c|c|c|c|c|c|c|}
\hline \multirow{3}{*}{$\begin{array}{l}\text { Management } \\
\text { system }^{\mathrm{z}}\end{array}$} & \multirow{2}{*}{\multicolumn{2}{|c|}{$\begin{array}{c}\text { Organic } \\
\text { matter }(\%)\end{array}$}} & \multicolumn{8}{|c|}{ Nutrient content (ppm) } & \multirow{2}{*}{\multicolumn{2}{|c|}{$\mathrm{pH}$}} & \multirow{2}{*}{\multicolumn{2}{|c|}{$\mathrm{CEC}(\mathrm{mg} / 100 \mathrm{~g})$}} \\
\hline & & & \multicolumn{2}{|c|}{$\mathrm{P}$} & \multicolumn{2}{|c|}{$\mathrm{K}$} & \multicolumn{2}{|c|}{$\mathrm{Mg}$} & \multicolumn{2}{|c|}{$\mathrm{Ca}$} & & & & \\
\hline & 1990 & 1993 & 1990 & 1993 & 1990 & 1993 & 1990 & 1993 & 1990 & 1993 & 1990 & $\overline{1993}$ & 1990 & 1993 \\
\hline $\mathrm{CC}-\mathrm{G}^{\mathrm{y}}$ & 3.07 & $3.48 \mathrm{a}^{{ }^{*} \mathrm{x}}$ & 36.0 & $47.8^{*}$ & 173 & $243^{*}$ & 292 & $307^{*}$ & 2420 & 2390 & 6.30 & $6.51 \mathrm{a}^{*}$ & 166 & 162 \\
\hline CC-D & 3.20 & $3.44 \mathrm{a}^{*}$ & 36.0 & $44.4^{*}$ & 178 & $231^{*}$ & 282 & $299^{*}$ & 2470 & 2430 & 6.57 & $6.72 \mathrm{~b}$ & 162 & 158 \\
\hline $\mathrm{CT}$ & 3.27 & $3.15 \mathrm{~b}$ & 33.0 & $46.2^{*}$ & 186 & $229^{*}$ & 287 & $303^{*}$ & 2490 & $2330^{*}$ & 6.50 & $6.67 \mathrm{~b}$ & 168 & $155^{*}$ \\
\hline
\end{tabular}

${ }^{\mathrm{z}}$ Management systems were: CC-G, rye and hairy vetch killed with glyphosate and mowed; CC-D, rye and hairy vetch mowed and disked; and CT, conventional tillage with trifluralin.

yThere were no differences in soil tests between vegetable cropping sequences within cover crop management systems.

${ }^{x}$ Mean separation within columns (lowercase letters) by Fishers LSD, $P=0.05$. *Significantly different 1990 and 1993 data by $t$ test, $P=0.05$.

out most of the growing season, and July and August had more than $10 \mathrm{~cm}$ of rainfall above average (Fig. 4). The high rainfall may have reduced caterpillar populations especially diamondback moth. In 1992, there were fewer cabbage caterpillars at 7 WAP in the CCG than CT treatment (Table 3). During 1993, there were more cabbage loopers, at $7 \mathrm{WAP}$, in the CT than cover-crop treatments.

Bugg et al. (1990) and Byers and Stromberg (1987) also found that cover crops reduce insect populations in cabbage. These effects could be due to conservation of beneficial insects in reduced tillage systems or reduced pest colonization of cabbage grown in cover-crop residues (Bugg, 1992). Although the cabbage caterpillar complex can be reduced by cover-crop mulch systems, additional control measures may be needed in most years to produce commercially acceptable cabbage. Our cabbage plots were not treated with insecticides and insect damage was considerable by fresh-market standards.

Initial soil properties were similar for the three cropping systems (Table 4) and nutrients levels considered adequate for vegetable crops (Lorenz and Maynard, 1988). There were treatment differences in the final soil test results. Rye and hairy vetch have been shown to produce between 190 and $950 \mathrm{~g} \cdot \mathrm{m}^{-2}$ of residues per year (Mwaja, 1994). These residues increased organic matter in the CC-G and CC-D treatments from about $3.1 \%$ to $3.4 \%$, while organic matter remained the same in the CT (Table 4). Organic matter was greater with the $\mathrm{CC}-\mathrm{G}$ and $\mathrm{CC}-\mathrm{D}$ treatments than with CT. Eckert (1991) also reported that organic matter may accumulate in no-till cropping systems with rye cover crops.

In the $\mathrm{CC}-\mathrm{G}$ treatment, the soil $\mathrm{pH}$ increased during the experiment from 6.30 to 6.51 , but because the initial $\mathrm{pH}$ was low, the final $\mathrm{pH}$ was still lower than in the other two treatments (Table 4). For example, the final $\mathrm{pH}$ for the $\mathrm{CT}$ was 6.67. The exact cause of these $\mathrm{pH}$ differences is unknown. In a study of rye cover crops in corn, Eckert (1991) also found in two out of three cases the soil $\mathrm{pH}$ was higher in rye plots. This effect was due to the rye assimilating nitrogen into organic matter.

Soil phosphorus, potassium, and magnesium were increased by all treatments during the study. Fertilizer applications in 1992 and 1993 may have contributed to this increase. Fall plowing and cover crops also may have brought nutrients up from deeper soil depths (Doss et al., 1981; Hairston et al., 1987). Eckert (1991) reported that rye increased the concentration of exchangeable potassium near the soil surface. Calcium levels and cation exchange capacity (CEC) were decreased by the CT treatment during our study. Potassium and acid cations tend to replace calcium at the soil surface, which could lead to its loss through leaching (Eckert, 1991).

Although cover-crop mulch systems improve can soil attributes and reduce weed and insect pest populations, they also may reduce tomato yields. In our study, yield reductions were not overcome by incorporating the cover crops or by using an intercrop of hairy vetch and rye. The yield reductions may have been caused by immobilization of nitrogen, cooler soil temperatures, or allelopathy. Strip tillage, which tills the row where vegetables are planted and leaves residues between crop rows, may overcome reduced vegetable yields while combining the advantages of both CT and cover-crop mulch systems (Wilhot et al., 1990).

\section{Literature Cited}

Andow, D.A. 1991. Vegetational diversity and arthropod response. Annu. Rev. Entomol. 36:561-586.

Barnes, J.P. and A.R. Putnam. 1983. Rye residues contribute weed 
suppression in no-tillage cropping systems. J. Chem. Ecol. 9:10451057.

Bugg, R.L. 1992. Using cover crops to manage arthropods on truck farms. HortScience 27:741-745.

Bugg, R.L., S.C. Phatack, and J.D. Dutcher. 1990. Insects associated with cool-season cover crops in southern Georgia: Implications for pest control in truck-farm and pecan agroecosystems. Biol. Agr. Hort. 7:1745.

Bushnell, J., C. Francis, and J. King. 1991. Design of resource efficient environmentally-sound cropping systems. J. Sustainable Agr. 4:49-65.

Byers, R.A. and E.L. Stromberg. 1987. Influence of legumes on insects and diseases in conservation tillage systems, p. 61-67. In: J. F. Power (ed.). The role of legumes in conservation tillage systems. Soil Conserv. Soc. of Amer., Akery, Iowa.

Curran, W.S., L.D. Hoffman, and E.L. Werner. 1994. The influence of a hairy vetch (Vicia villosa) cover crop on weed control and corn (Zea mays) growth and yield. Weed Technol. 8:777-784.

Dickson, M.H. and C.J. Eckenrode. 1980. Breeding for resistance in cabbage and cauliflower to cabbage looper, imported cabbageworm, and diamondback moth. J. Amer. Soc. Hort. Sci. 105:782-785.

Doss, D.B., J.L. Turner, and C.E. Evans. 1981. Influence of tillage, nitrogen, and rye cover crop on the growth and yield of tomato. J. Amer. Soc. Hort. Sci. 106:95-97.

Drost, D.T. and H.C. Price. 1991. Effect of tillage system and planting date on growth and yield of transplanted tomato. HortScience 26:1478-1480.

Eckert, D.J. 1991. Chemical attributes of soils subjected to no-till cropping with rye cover crops. Soil Sci. Soc. Amer. J. 55:405-409.

Hairston, J.E., J.O. Sanford, D.F. Pope, and D.A. Horneck. 1987. Soybean-wheat double cropping: Implications from straw management and supplemental nitrogen. Agron. J. 79:281-286.

Johnson, G.A., M.S. Defelice, and Z.R. Helsel. 1993. Cover crop management and weed control in corn. Weed Technol. 7:425-430.

Knavel, D.E. and J.W. Herron. 1986. Response of vegetable crops to nitrogen rates in tillage systems with and without vetch and ryegrass. J. Amer. Soc. Hort. Sci. 111:502-507.
Lorenz, O.A. and D.N. Maynard. 1988. Knott's handbook for vegetable growers. 3rd ed. Wiley, New York.

Masiunas, J.B., L.A. Weston, and S.C. Weller. 1995. The impact of rye cover crops on weed populations in a tomato cropping system. Weed Sci. 43:318-323.

More, M.J., T.J. Gillespie, and C.J. Swanton. 1994. Effect of cover crop mulch on weed emergence, weed biomass, and soybean (Glycine max) development. Weed Technol. 8:512-518.

Mwaja, V.N. 1994. The impact of allelopathic winter rye (Secale cereale L.) and hairy vetch (Vicia villosa Roth) residues on a vegetable cropping system. PhD diss., Univ. of Illinois, Urbana.

Mwaja, V.N., J.B. Masiunas, and L.A. Weston. 1995. The effect of fertility on biomass, phytotoxicity, and allelochemical content of cereal rye. J. Chem. Ecol. 21:81-96.

Perez, F.G.M. and J.B. Masiunas. 1990. Eastern black nightshade (Solanum ptycanthum) interference in processing tomato (Lycopersicon esculentum). Weed Sci. 38:385-388.

Rice, E.L. 1984. Allelopathy. 2nd ed. Academic Press, New York.

Schonbeck, M., S. Herbert, R. DeGregorio, F. Mangan, K. Guillard, E. Sideman, J. Herbst, and R. Jaye. 1993. Cover cropping system in the northeastern United States: I. Cover crop and vegetable yields, nutrients, and soil conditions. J. Sustainable Agr. 3:105-132.

Skarphol, B.J., K.A. Corey, and J. J. Meisinger. 1987. Response of snap beans to tillage and cover crop combinations. J. Amer. Soc. Hort. Sci. 112:936-941.

Swiader, J.M., G.W. Ware, and J.P. McCollum. 1993. Producing vegetable crops. Interstate Publisher, Danville, Ill.

Teasdale, J.R. 1993. Reduced-herbicide weed management systems for no-tillage corn (Zea mays) in a hairy vetch (Vicia villosa) cover crop. Weed Technol. 7:879-883.

Teasdale, J.R., C.E. Beste, and W.E. Potts. 1991. Response of weeds to tillage and cover crop residues. Weed Sci. 39:195-199.

Wilhot, J.H., R.D. Morse, and D.H. Vaughan. 1990. Strip-tillage production of summer cabbage using high residue levels. Appl. Agr. Res. $5: 338-342$. 